DOI https://doi.org/10.30525/978-9934-26-004-9-107

\title{
АНАЛИЗ ГЕНЕЗИСА ВЫСОТНОЙ БИОКЛИМАТИЧЕСКОЙ АРХИТЕКТУРЫ
}

\author{
Кривенко О. В. \\ кандидат технических наук, доцент, \\ дочент кафедры архитектурных конструкций \\ Киевского национального университета \\ строительства и архитектуры \\ г. Киев, Украина
}

Научно - технический прогресс кардинально изменил стиль, условия жизни современного человека, а соответственно и требования, подходы к архитектуре зданий. C конца XX века начался процесс урбанизации, который привел к застройке городов высотными зданиями. Урбанизация неизбежна и является одной из основных тенденций нашего века, она связана в первую очередь с ростом населения в мире (рис.1). По данным Организации Объединенных Наций, более 50\% населения Земли уже проживает в городах, а к 2050 году более двух третей населения мира станут городскими жителями [1].

Высотное строительство относится к одному из направлений современного градостроительного развития, основанного на принципах интегрированного урбанизма. XXI век определяется неуклонным ростом количества высотных зданий в мире $\mathrm{c}$ широкой географией строительства (рис. 2), [2]. Потребность в обеспечении места жительства, работы для растущего населения в городах обеспечивается развитием высотной застройки. За счет компактности высотной застройки в городах решается проблема нехватки места под застройку и необходимой инфраструктуры. Развитие новых технологий обеспечивает функционирование высотных зданий с искусственным микроклиматом, что позволяет особо не учитывать природно - климатические условия при проектировании зданий. Следствием чего стали значительные энергозатраты, рост отходов производства и строительства, высокая концентрация продуктов жизнедеятельности людей, что постепенно приводит к разрушению окружающей среды [3, с. 1]. Формируется преимущественно искусственная среда проживания людей в городах, что влияет на их физическое и психологическое состояние. Природа 
вытесняется из урбанизированной среды городов, чем ухудшается их экология.

Рост объемов потребления и строительства заставляет человечество задуматься над вопросом сохранения природной среды. Актуальным сегодня становится внедрение концепции «устойчивого развития». В высотной архитектуре концепция «устойчивого развития» приобрела реализацию в виде «зеленого» или экологического дизайна зданий. Сегодня «зеленый дизайн» в высотной архитектуре является общим направлением, включает различные подходы и факторы, которые делают здания устойчивыми [4, с. 337].

Биоклиматическая архитектура представляет отдельное направление развития в экологической «зеленой» архитектуре, которая сформирована следующими факторами:

- влияние климата на архитектурно - строительные решения зданий;

- сокращение природных ресурсов;

- энергетический кризис;

- негативное влияние искусственной среды на человека.

Целью биоклиматического проектирования является создание архитектуры, которая обладает качествами элемента природной экосистемы для решения проблемы гармонии живого и неживого в архитектуре (рис. 3). Проектирование биоклиматической архитектуры основывается на учете параметров климата, которые, несмотря на их изменчивость, составляют объективную основу, обеспечивает логику процесса биоклиматического проектирования [5, с.8].

Применение биоклиматического подхода в высотной архитектуре, возвращает ее к принципам возведения традиционной архитектуры, с ее максимальной адаптацией к окружающей среде с учетом климатических, социальных и экологических факторов местности. Такой подход уменьшает потребность в применении энергозатратных технологий при обеспечении жизнедеятельности здания и комфорта людей.

Таким образом, в основе генезиса высотной биоклиматической архитектуры (рис. 4) лежат мировые тенденции роста населения, урбанизации, интенсивного развития высотной архитектуры. Эти тенденции привели к формированию энергетического и экологического кризиса в мире, что в свою очередь дало толчок к развитию новых устойчивых подходов для его преодоления. Биоклиматическая высотная архитектура направлена на создание новой ориентированной на природу среды обитания человека в городах, что является необходимой потребностью современности. 


\title{
Література:
}

1. Urbanization: insights in a global megatrend. Governance and economy 2017-05-02. https://smartcityhub.com/governance-economy/urbanizationinsights-in-a-global-megatrend/ (дата обращения 08.11.2020).

2. Routley N. Charting the Last 20 Years of Supertall Skyscrapers. https://www.visualcapitalist.com/charting-the-last-20-years-of-supertallskyscrapers/(дата обращения 08.11.2020).

3. Ellis P.G., Torcellini P.A. SIMULATING TALL BUILDINGS USING ENERGYPLUS. Ninth International Building Performance Simulation Association (IBPSA) Conference and Exhibition (Building Simulation 2005), Montreal, Quebec, August 15-18, 2005.

4. Кривенко О.В. Задачи и направления применения природных аналогов при проектировании высотных биоклиматических зданий. «Архітектурний вісник КНУБА». - К.: КНУБА, 2019. - № 20. C. 337-342. DOI: $10.32347 / 2519-8661.2019-20.193601$

5. Krivenko O., Mileikovskyi V., Tkachenko T. The principles of energy efficient microclimate provision in the skyscraper «Biotecton» of $1 \mathrm{~km}$ height// European Journal of Formal Sciences and Engineering, ISSN 26018683, volume 1, Issue 3, 2018, p 8-17. http://dx.doi.org/10.26417/ ejef.v2i3.p66-75

DOI https://doi.org/10.30525/978-9934-26-004-9-108

\section{ЕВОЛЮЦІЯ МОТОРИЗОВАНИХ ТРАНСПОРТНИХ ЗАСОБІВ ЯК ГОЛОВНИЙ ЧИННИК ФОРМОУТВОРЕННЯ ОДЯГУ ВОДІЇВ}

\author{
Крічлоу К. В. \\ аспірант кафедри ергономіки і дизайну
}

Колосніченко О. В.

доктор мистеитвознавства, професор кафедри художнього моделювання костюма, Київського національного університету технологій та дизайну м. Київ, Украӥна

В сучасному житті одяг для водії моторизованих транспортних засобів МТЗ є явищем проектної культури, як і одяг будь-якої іншої сфери людського життя [1-2]. Стрімкий розвиток технологічного та культурного прогресу $€$ одним 3 факторів його популяризації та 